\title{
Presynaptic modulation of GABAergic transmission onto striatal cholinergic interneuron by M1 acetylcholine receptor activation
}

\author{
Etsuko Suzuki, Toshihiko Momiyama \\ Department of Pharmacology, Jikei University School of Medicine, Japan
}

In the striatum, acetylcholine has modulatory action on neurotransmitter release onto medium spiny neurons (MSNs). We examined modulatory role of acetylcholine receptor activation on GABAergic transmission from MSNs onto striatal cholinergic interneurons. To selectively stimulate MSNs, we used transgenic mice with restricted expression of channelrhodopsin-2 (ChR2) in MSNs. Whole-cell patch-clamp recordings were made from striatal cholinergic interneurons in P10-17 mice brain slices. Neurons were voltage clamped at -60 mV. Light stimulation $(470 \mathrm{~nm}, 5 \mathrm{~ms}$ duration) evoked synaptic currents in the presence of glutamatergic and glycinergic receptors antagonists. These currents were reversively blocked by bicuculline, suggesting that they are GABAA receptor-mediated inhibitory postsynaptic currents (IPSCs). A musucarinic receptor agonist, carbachol $(1 \mu \mathrm{M})$, suppressed light-evoked IPSCs (by $49.5 \pm 7.8 \%$ of baseline, $n=5)$. In the presence of M1 musucarine receptor antagonist, pirenzepine $(1 \mu \mathrm{M})$, the inhibitory effect of carbachol on IPSCs reduced to $5.2 \pm 3.5 \%(\mathrm{n}=7, \mathrm{P}<0.01)$. However, membrane impermeable M1 receptor antagonist, MT-7 (100 nM), did not antagonize the inhibitory effect of carbachol (by $51.4 \pm 3.7 \%$ of baseline, $n=6$ ), suggesting that intracellular M1 receptors are responsible for the inhibitory effect of carbachol. To address the action site of carbachol, presynaptic or postsynaptic, GDP $\beta$ S was loaded into the cholinergic interneurons via patch pipette to inhibit the intracellular G-protein cascade. In this condition, IPSCs were still inhibited by carbachol (by $61.3 \pm 3.9 \%$ of baseline, $\mathrm{n}=8)$. Paired-pulse ratio (PPR) before carbachol application was $0.75 \pm 0.04(\mathrm{n}=30)$, that was significantly increased after carbachol application to $0.97 \pm 0.05(\mathrm{P}<0.01)$, suggesting that GABA release probability was decreased by carbachol. These results suggest that carbachol inhibits GABA release from MSNs onto cholinergic interneurons via M1 muscarinic acetylcholine receptors. 